Volume 03 Nomor 01, Juni 2021 Page 32-44

Incrementapedia: Jurnal Pendidikan Anak Usia Dini

Program Studi PG-PAUD Fakultas Pedagogi dan Psikologi

Universitas PGRI Adi Buana Surabaya

http://jurnal.unipasby.ac.id/index.php/incrementapedia

e-ISSN: 2686-3146

\title{
ANALISIS IMPLEMENTASI SIPERAN (SISTEM \\ PERANGKAT PEMBELAJARAN) BERBASIS SINGLE USER DALAM PENYUSUNAN PERANGKAT PEMBELAJARAN DI KB- TK ISLAM AL FATH SEMARANG
}

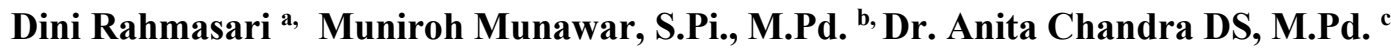 \\ anniversitas PGRI Semarang \\ ${ }^{b}$ Universitas PGRI Semarang \\ 'Universitas PGRI Semarang \\ e-mail korespondensi: dini.salma75@gmail.com
}

\begin{abstract}
The background that drives this research is that there are no schools that use an integrated learning tool system starting from the preparation of the RPPM to the assessment process. An integrated system is urgently needed to ease the burden on teachers in the preparation of learning tools. The preparation of efficient and effective learning tools using computer technology is very important for educators. Based on the research context, the focus of the problem in this study is "How is the implementation of single userbased Siperan (Learning Device System) in the preparation of learning tools in KB-TK Islam Al Fath Semarang?" The aim of this research is to describe the implementation of Siperan (Learning Device System) based on a single user in the preparation of learning tools in KB-TK Islam Al Fath Semarang.

This study uses descriptive qualitative research methods in the form of words, writing, oral, and pictures. The location of this research was carried out in Al Fath Islamic Kindergarten, Semarang. Data comes from person, place, process, and paper. The data collection procedure was carried out by observation, interviews, and documentation. The results of research conducted at KB-TK Islam Al Fath Semarang, Implementation of Siperan (Learning Device System) based on Single User has a positive impact in the process of preparing learning tools. The ease of operating the Siperan template has made it easy for teachers to complete administrative tasks ranging from preparing lesson plans to making assessments, whether it be daily assessments, weekly recaps, monthly recaps and making anecdotal notes. The Siperan template has complete components and is in accordance with the K13 PAUD guidelines.

Based on the results of this study, the suggestion that can be submitted is that the Single User-based Siperan (Learning Device System) can be used as an alternative teacher in the process of preparing learning tools, especially the level of Early Childhood Education.
\end{abstract}

Keywords: Siperan, integrated system, single user

\section{PENDAHULUAN}

Undang-Undang Nomor 20 Tahun 2003 tentang Sistem Pendidikan Nasional menyatakan bahwa Pendidikan adalah usaha sadar dan terencana untuk mewujudkan suasana belajar dan proses pembelajaran agar peserta didik secara aktif mengembangkan potensi dirinya untuk memiliki kekuatan spiritual keagamaan, pengendalian diri, kepribadian, kecerdasan, akhlaq mulia, serta keterampilan yang diperlukan dirinya, masyarakat, bangsa, dan negara. Berdasarkan undang-undang tersebut, perencanaan yang baik sangat dibutuhkan untuk proses pendidikan. 
Salah satu jenjang pendidikan adalah Pendidikan Anak Usia Dini yang selanjutnya diistilahkan dengan PAUD. Menurut Undangundang nomor 20 tahun 2003 tentang Sistem Pendidikan Nasional Pasal 1 angka 14 menyatakan bahwa Pendidikan Anak Usia Dini adalah suatu upaya pembinaan yang ditujukan kepada anak sejak lahir sampai dengan usia enam tahun yang dilakukan melalui pemberian rangsangan pendidikan untuk membantu pertumbuhan dan perkembangan jasmani dan rohani agar anak memiliki kesiapan dalam memasuki pendidikan lebih lanjut.

Predikat "guru" tidak bisa diemban oleh sembarang orang. Hamzah Uno dalam buku $B e A$ Great Teacher karya Barnawi (2012:35) mengatakan, "guru merupakan suatu profesi yang memerlukan keahlian khusus dan tidak dapat dilakukan oleh sembarang orang di luar pendidikan". Guru harus benar-benar memiliki keahlian di bidangnya. Keahlian itu juga harus ditopang oleh dua standar penting yaitu standar kualifikasi akademik dan standar kompetensi guru. Kedua hal tersebut harus dipenuhi seorang guru agar dapat disebut sebagai guru profesional. Standar kualifikasi akademik yang dimaksud adalah guru seharusnya mengajar sesuai dengan latar belakang pendidikannya. Seperti contoh, guru PAUD minimal harus lulusan sarjana (S1) Pendidikan Guru Pendidikan Anak Usia Dini di program studi yang terakreditasi. Hal itu juga berlaku untuk guru yang mengajar pada jenjang pendidikan masing-masing. Selain standar kualifikasi akademik yang sesuai, untuk menjadi seorang guru profesional juga dibutuhkan pemenuhan terhadap standar kompetensi guru.
Selain itu guru merupakan salah satu profesi yang ditandai dengan penguasaan empat kompetensi yang diantaranya adalah kompetensi profesional dan kompetensi pedagogik (Undang-undang No. 14 Tahun 2005 tentang Guru dan Dosen). Standar kompetensi guru terdiri dari empat kompetensi yaitu kompetensi profesional, kompetensi pedagogik, kompetensi sosial, dan kompetensi kepribadian. Keempat kompetensi ini wajib dipenuhi oleh guru profesional. Profesional adalah pekerjaan atau kegiatan yang dilakukan oleh seseorang dan menjadi sumber penghasilan kehidupan yang memerlukan keahlian, kemahiran, atau kecakapan yang memenuhi standar mutu atau norma tertentu serta memerlukan pendidikan profesi. Guru harus terlebih dahulu menyiapkan dirinya menjadi pribadi yang responsive, adaptif, dan handal yang mampu menggunakan dan memanfaatkan teknologi yang berkembang pesat saat ini. Selain kompetensi profesional, guru juga harus menguasai kompetensi pedagogik, yaitu kemampuan dan pemahaman terhadap peserta didik, perencanaan, dan pelaksanaan pembelajaran, evaluasi hasil belajar, dan pengembangan peserta didik untuk mengaktualisasikan berbagai potensi yang dimilikinya. Berdasarkan pengertian tersebut, diketahui bahwa guru harus dapat merancang pembelajaran sebelum melakukan pembelajaran kepada anak usia dini.Dua standar tersebut mengantarkan guru pada pemahaman tentang apa saja tugas-tugas seorang guru baik secara fungsional, struktural, maupun administrasinya.

Salah satu standar yang penting untuk dipenuhi setiap lembaga adalah standar proses. Sebagaimana tertuang dalam Peraturan Menteri Pendidikan dan Kebudayaan Republik Indonesia 
nomor 137 tahun 2014 tentang Standar Nasional Pendidikan Anak Usia Dini Bab V Pasal 11 menyatakan bahwa standar proses mencakup: 1) Perencanaan pembelajaran, 2) pelaksanaan pembelajaran, 3) evaluasi pembelajaran, dan 4) pengawasan pembelajaran. Selanjutnya pada pasal 12 menerangkan bahwa 1) Perencanaan pembelajaran sebagaimana dimaksud pada pasal 11 huruf a dilakukan dengan pendekatan dan model pembelajaran yang sesuai dengan kebutuhan, karakteristik anak, dan budaya lokal, 2) perencanaan pembelajaran meliputi: (a) Program semester yang selanjutnya diistilahkan dengan Prosem, (b) Rencana pelaksanaan pembelajaran mingguan yang biasa disebut dengan RPPM, dan (c) Rencana pelaksanaan pembelajaran harian atau disingkat dengan RPPH, 3) Perencanaan pembelajaran disusun oleh guru pada satuan atau program PAUD.

Tugas-tugas administrasi guru tersebut dibuat bertujuan untuk mempermudah pelaksanaan pembelajaran anak dari skala tahunan sampai skala harian. Luluk (2014:15) berpendapat, "Perencanaan pembelajaran adalah suatu proses untuk menentukan ke mana harus pergi dan mengidentifikasi persyaratan yang diperlukan dengan cara yang paling efektif dan efisien". Sependapat dengan Luluk, Eve Marie dan Susan (2013:193) mengatakan, "Planning maximizes the use of time, and in that way, increases opportunities for quality interaction among the teachers and children", perencanaan memaksimalkan penggunaan waktu, dan dengan cara itu, meningkatkan peluang untuk interaksi berkualitas di antara para guru dan anak-anak. Kedua pendapat tersebut menjabarkan alasan mengapa perencanaan di awal merupakan kunci penting dalam pembelajaran yaitu efektivitas dan efesiensi untuk mencapai tujuan-tujuan pembelajaran di PAUD. Pembuatan tugas administrasi guru atau perencanaan pembelajaran tidak hanya berguna sebagai dokumen pelengkap dari arsip sekolah saja, melainkan harus direalisasikan dengan baik dalam proses pelaksanaannya.

Berdasarkan pengamatan di lapangan, belum ada sekolah di wilayah kecamatan Pedurungan yang menggunakan sistem perangkat pembelajaran yang terintegrasi mulai dari penyusunan RPPM hingga proses penilaian. Sangat dibutuhkan sistem yang terintegrasi untuk meringankan beban guru dalam penyusunan perangkat pembelajaran.

Sujoko dalam Rohita (2019:2) menyatakan bahwa Teknologi Informasi dan Komunikasi (TIK) adalah sekumpulan perangkat dan sumber daya teknologi yang digunakan untuk berkomunikasi, penciptaan, penyebaran, penyimpanan, dan pengolahan informasi atau teknologi yang dapat mereduksi batasan ruang dan waktu untuk mengambil, memindahkan, menganalisa, menyajikan, menyimpan, dan menyampaikan informasi data menjadi sebuah informasi. Salah satu manfaat TIK dalam pendidikan adalah sebagai alat bantu pembelajaran bagi guru, yang meliputi animasi peristiwa, alat uji siswa, sumber referensi ajar, evaluasi kinerja siswa, simulasi kasus, alat peraga visual, dan media komunikasi antar guru. Ungkapan berikutnya disampaikan oleh Parsaoratan dkk dalam Rohita (2019:2) bahwa dalam dunia pendidikan, teknologi informasi dan komunikasi juga berperan dalam mempermudah 
pengurusan administrasi akademik, pendaftaran, maupun proses belajar mengajar.

Sistem operasi merupakan program utama pada komputer yang menghubungkan antara software yang digunakan oleh user dengan hardware. Berdasarkan jumlah penggunanya, sistem operasi dibedakan menjadi sistem operasi single user dan sistem operasi multi user. Sistem operasi single user yaitu sebuah sistem operasi yang hanya menyediakan akses ke sistem komputer ke satu pengguna sekaligus. Apabila ada pengguna lain yang akan mengakses sistem komputer, maka yang sudah menggunakan komputer harus sudah selesai menggunakan komputer. Contoh sistem operasi single user adalah Windows. Penyusunan perangkat pembelajaran nantinya akan menggunakan program Microsoft Excel pada Windows untuk memudahkan tenaga pendidik dalam penyelesaiannya.

Penyusunan perangkat pembelajaran yang efisien dan efektif dengan menggunakan teknologi komputer sangat penting bagi pendidik, diharapkan pendidik akan mampu lebih kreatif dalam pembelajaran anak usia dini bilama beban tugas administrasi tidak terlalu berat.

Permasalahan administrasi guru di KB-TK Islam Al Fath Semarang seperti masalah penyusunan RPPM, RPPH, dan penilaian siswa seringkali membuat guru menjadi kehabisan waktu dan berakibat kurangnya kreativitas guru dalam menyiapkan kegiatan-kegiatan pembelajaran yang menarik bagi siswanya. Hal tersebut senada dengan yang disampaikan oleh kepala TK Islam Al Fath Semarang, Ibu Ulfah, S.Pd. mengatakan bahwa, "Tuntutan beban administrasi dari dinas untuk guru TK pada saat ini sangatlah banyak, hal tersebut seringkali membuat guru TK menjadi sangat sibuk sehingga akhirnya membuat guru tidak sempat melakukan persiapan yang matang untuk pembelajaran anak-anak, bilamana pembelajaran kurang menarik, maka anak-anak akan merasa bosan dan berakibat kurangnya minat anak untuk bermain dan belajar di TK". Hakekat utama seorang guru TK adalah memberikan pendidikan dan pembelajaran yang menarik kepada siswanya sesuai dengan usia perkembangan anak. Tugas adminitrasi yang menjadi tanggung jawab guru hendaknya dapat terselesaikan tepat waktu dengan tidak mengurangi fungsi utama seorang guru TK. Perlu adanya implementasi sistem yang terintegrasi dalam penyusunan RPPM, RPPH, dan Penilaian untuk mampu menyelesaikan semua permasalahan yang timbul di KB-TK Islam Al Fath Semarang. Implementasi "siperan" Sistem Perangkat Pembelajaran diharapkan mampu menjadikan tugas adminitrasi guru menjadi lebih ringan.

Berdasarkan pemaparan permasalahan yang ada, maka penelitian ini bertujuan untuk menganalisa implementasi "siperan" sistem perangkat pembelajaran berbasis single user dalam penyusunan perangkat pembelajaran di KB-TK Islam Al Fath Semarang.

\section{METODE PENELITIAN}

Penelitian ini adalah penelitian dengan jenis penelitian kualitatif. Sugiono (2017: 8-9) mendefinisikan metode kualitatif adalah metode penelitian yang berlandaskan pada filsafat postpositivisme, digunakan untuk meneliti pada kondisi obyek yang alamiah, dimana peneliti 
adalah sebagai instrument kunci, teknik pengumpulan data dilakukan secara triangulasi (gabungan), analisis data bersifat induktif/kualitatif, dan hasil penelitian kualitatif lebih menekankan makna dari pada generalisasi.

Dengan penelitian kualitatif, perlu dilakukan analisis deskriptif. Metode analisis deskriptif memberikan gambaran dan keterangan yang secara jelas, objektif, sistematis, analisis dan kritis mengenai implementasi siperan sistem perangkat pembelajaran berbasis single user dalam penyusunan perangkat pembelajaran di TK Islam Al Fath. Pendekatan kualitatif yang didasarkan pada langkah awal yang ditempuh dengan mengumpulkan data-data yang dibutuhkan, kemudian dilakukan klasifikasi dan deskripsi.

Penelitian ini bertujuan mendeskripsikan bagaimana implementasi Siperan (Sistem Perangkat Pembelajaran) berbasis single user dalam penyusunan perangkat pembelajarn ditinjau dari produktifitas, semangat kerja, kepuasan kerja, penerimaan tujuan lembaga, dan keterpaduan bagi guru.

Lokasi penelitian tersebut adalah TK Islam Al Fath, yang beralamat di Jl. Graha Mukti Utama Raya 344B perumahan Graha Mukti Utama, Kelurahan Tlogomulyo, Kecamatan Pedurungan, Kota Semarang, Propinsi Jawa Tengah.

Penelitian ini dilaksanakan pada bulan Januari hingga bulan Maret 2021 atau semester genap tahun 2020-2021.

Data yang digunakan dalam penelitian ini adalah menggunakan jenis data kualitatif. Data kualitatif merupakan data yang menunjukkan kualitas atau sesuatu yang ada, baik keadaan, proses, peristiwa/kejadian dan lainnya yang dinyatakan dalam bentuk pernyataan atau berupa kata-kata. Penentuan kualitas data itu menuntut kemampuan menilai tentang bagaimana mutu sesuatu itu (Widoyoko, 2017: 18).

Data ini biasanya diperoleh dari hasil wawancara dan bersifat subjektif sebab data tersebut dapat ditafsirkan lain oleh orang yang berbeda. Data kualitatif dapat diangkakan (kuantifikasi) dalam bentuk ordinal atau rangking.

Data yang dibutuhkan dalam penelitian dapat dikumpulkan atau diperoleh dari berbagai sumber data. Pengertian sumber data dalam penelitian adalah subjek darimana data dapat diperoleh (Widoyoko, 2017: 29).

Berdasarkan subjek dimana data melekat, sumber data dapat diklasifikasikan menjadi 4 singkatan huruf $p(4 p)$ dari bahasa inggris sebagai berikut:

1. Person, yaitu sumber data bisa memberikan data berupa jawaban lisan melalui wawancara atau jawaban tertulis melalui angket. Sumber data person disebut dengan responden. Dalam penelitian ini adalah guru.

2. Place, yaitu sumber data yang berupa tempat, seperti penelitian bertempat di sekolah TK Islam Al Fath Semarang

3. Process, yaitu sumber data yang berupa aktivitas atau kegiatan seperti aktivitas penyusunan perangkat pembelajaran

4. Paper, yaitu sumber data yang berupa symbol, huruf, angka, gambar, seperti gambar yang ada di foto saat guru sedang menyusun perangkat pembelajaran maupun 
bentuk pendokumentasian kegiatan lainnya seperti video.

Dalam penelitian kualitatif tersebut, yang menjadi instrumen utama adalah peneliti sendiri.

Dalam penelitian kualitatif, peneliti adalah sebagai instrumen kunci (human instrumen). Untuk dapat menjadi instrumen penelitian yang baik, peneliti kualitatif dituntut untuk memiliki wawasan yang luas, baik wawasan teoritis maupun wawasan yang terkait dengan konteks sosial yang diteliti yang berupa nilai, budaya, keyakinan, hukum, adat istiadat yang terjadi dan berkembang pada konteks sosial tersebut (Sugiyono, 2018: 88).

Teknik pengumpulan data merupakan langkah yang paling utama dalam penelitian, karena tujuan utama dari penelitian adalah mendapatkan data (Sugiyono, 2017: 137). Adapun teknik pengumpulan data yang digunakan dalam penelitian ini adalah :

1. Observasi

Observasi yang dilakukan dalam penelitian ini adalah observasi partisipasif atau observasi berperan serta (participant Observation), yaitu dalam observasi ini peneliti terlibat dengan kegiatan sehari-hari orang yang sedang diamati atau yang digunakan sebagai sumber data penelitian. Sambil melakukan pengamatan, peneliti ikut melakukan apa yang dikerjakan oleh sumber data, dan ikut merasakan suka dukanya (Sugiyono, 2017: 145). Dengan observasi partisipan ini, maka data yang diperoleh akan lebih lengkap, tajam, dan sampai mengetahui pada tingkat makna dari setiap perilaku yang nampak.

2. Dokumentasi
Pengumpulan data dalam penelitian ini juga dilakukan pada arsip atau dokumen yang ada di sekolah, yaitu kurikulum yang digunakan baik promes maupun Rencana Pelaksanaan Pembelajaran (RPP).

3. Wawancara

Wawancara digunakan sebagai teknik pengumpulan data apabila peneliti ingin melakukan studi pendahuluan untuk menemukan permasalahan yang harus diteliti, tetapi juga apabila peneliti ingin mengetahui hal-hal dari responden yang lebih mendalam dan jumlah respondennya sedikit/kecil. (Sugiyono, 2017: 137).

Adapun wawancara yang dilakukan dalam penelitian ini yaitu wawancara terhadap kepala sekolah, dan guru mengenai proses penyusunan perangkat pembelajaran selama ini.

4. Triangulasi/gabungan

Dalam teknik pengumpulan data, triangulasi diartikan sebagai teknik pengumpulan data yang bersifat menggabungkan dari berbagai teknik pengumpulan data dan sumber data yang telah ada (Sugiyono, 2017: 241). Sedangkan menurut Susan Stainback (1988) dalam Sugiyono (2017: 241) menyebutkan bahwa tujuan dari triangulasi bukan untuk mencari kebenaran tentang berapa fenomena, tetapi lebih pada peningkatan pemahaman peneliti terhadap apa yang telah ditemukan. Melalui triangulasi dalam pengumpulan data, maka data yang diperoleh akan lebih konsisten, tuntas dan pasti, serta meningkatkan kekuatan data, bila dibandingkan dengan satu pendekatan.

Uji keabsahan data dalam penelitian kualitatif menurut Sugiono (2017: 270) dapat menggunakan uji kredibilitas. Uji kredibilitas data atau 
kepercayaan terhadap data hasil penelitian kualitatif dapat dilakukan dengan perpanjangan pengamatan, peningkatan ketekunan dalam penelitian, triangulasi, diskusi dengan teman sejawat, analisis kasus negative, dan membercheck.

Setelah proses pengumpulan data dilakukan, kemudian peneliti melakukan analisis data. Miles dan Huberman dalam Sugiono (2018: 132-142) mengemukakan bahwa aktivitas dalam analisis data kualitatif dilakukan secara interaktif dan berlangsung terus menerus sampai tuntas, sehingga datanya sudah jenuh. Aktivitas dalam analisis data yaitu:

\section{Data collection (Pengumpulan Data)}

Kegiatan utama dalam setiap penelitian adalah pengumpulan data. Dalam penelitian kualitatif pengumpulan data pada umumnya menggunakan kuesioner atau test tertutup. Data yang diperoleh adalah data kualitatif. Data tersebut selanjutnya dianalisis dengan statistik. Dalam penelitian kualitatifpengumpulan data dengan observasi, wawancara mendalam, dan dokumentaasi atau gabungan ketiganya (triangulasi). Pengumpulan data dilakukan berhari-hari, berbulan-bulan sehingga data yang diperoleh akan banyak. Pada tahap awal peneliti melakukan penjelajahan secara umum terhadap situasi sosial/objek yang diteliti, semua yang dilihat dan didengar direkam semua. Dengan demilian peneliti akan memperoleh data yang sangat banyak dan sangat bervariasi.

\section{Data reduction (Reduksi Data)}

Mereduksi data berarti merangkum, memilih hal-hal yang pokok, memfokuskan pada hal-hal yang penting, dicari tema dan polanya. Dengan demikian data yang telah direduksi akan memberikan gambaran yang lebih jelas, dan mempermudah peneliti untuk melakukan pengumpulan data selanjutnya, dan mencarinya bila diperlukan. Penilitian ini memfokuskan pada analisis implementasi siperan sistem perangkat pembelajaran berbasis single user dalam penyusunan perangkat pembelajaran di TK Islam Al Fath Semarang.

\section{Data Display (Penyajian Data)}

Penyajian data bisa dilakukan dalam bentuk uraian singkat, bagan, hubungan antar kategori, flowchart dan sejenisnya. Dalam penelitian ini, peneliti menyajikan data tentang analisis implementasi siperan sistem perangkat pembelajaran berbasis single user dalam penyusunan perangkat pembelajaran di TK Islam Al Fath Semarang dalam bentuk teks yang bersifat deskriptif.

\section{Conclusion Drawing/Verification}

Kesimpulan awal yang masih bersifat sementara, dan akan berubah apabila tidak ditemukan bukti - bukti kuat yang mendukung pada tahap pengumpulan data berikutnya. Tetapi apabila kesimpulan yang dikemukakan pada tahap awal di dukung oleh bukti-bukti yang valid dan konsisten saat peneliti kemballi ke lapangan mengumpulkan data, maka kesimpulan yang dikemukakan merupakan kesimpulan yang kredibel. Dalam penelitian ini, data tentang analisis implementasi siperan sistem perangkat pembelajaran berbasis single user dalam penyusunan perangkat pembelajaran di TK Islam Al Fath Semarang yang telah tertulis dalam penyajian data, dianalisis, untuk memperoleh kesimpulan. 


\section{HASIL PENELITIAN}

Hasil penelitian disusun berdasarkan hasil wawancara dan data-data tambahan berupa hasil observasi dan dokumentasi bukti penyusunan perangkat pembelajaran yang dilakukan oleh guruguru dalam penggunaan pada Sistem Perangkat Pembelajaran (Siperan) berbasis single user. Sebelum melakukan wawancara, peneliti membuat kesepakatan jam dan hari di mana akan dilakukan proses wawancara dengan para guru. Hasil wawancara dilakukan kepada kepala sekolah TK Islam Al Fath Semarang dan para guru yang menggunakan sistem perangkat pembelajaran (Siperan) berbasis single user, selanjutnya peneliti meminta ijin kepada kepala sekolah untuk melakukan proses penelitian baik itu untuk mendapatkan data dari metode observasi dan metode dokumentasi di lembaga ini.

Tabel 1. Temuan Hasil Observasi dan Dokumentasi

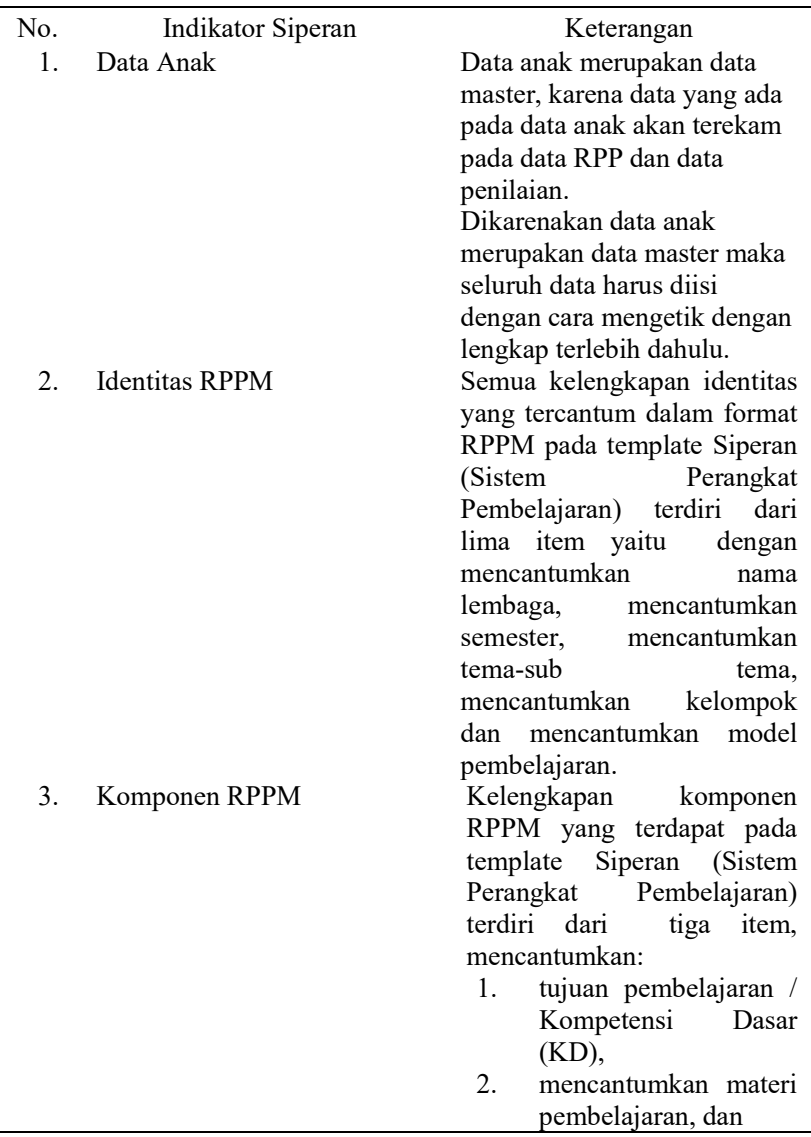

4. Komponen RPPH

5. Rubrik Penilaian

6. Komponen Penilaian Harian 7. Komponen Penilaian
Mingguan

3. mencantumkan rencana kegiatan.

Komponen tersebut disesuaikan dengan pedoman penyusunan RPPM Ditjen PAUD tahun 2018.

Kelengkapan komponen RPPH yang terdapat pada template Siperan (Sistem Perangkat Pembelajaran) adalah mencantumkan:

1. materi,

2. alat \& bahan,

3. kegiatan fisik motorik,

4. kegiatan pembukaan,

5. kegiatan inti,

6. kegiatan recalling,

7. kegiatan penutup.

Komponen tersebut disesuaikan dengan pedoman penyusunan RPPH Ditjen PAUD tahun 2018

Rubrik penilaian pada template Siperan (Sistem Perangkat Pembelajaran) terdiri dari dua item yaitu:

1. teknik penilaian

2. prosedur penilaian/skoring,

Format penilaian dalam template Siperan (Sistem Perangkat Pembelajaran) terdapat ceklis harian, mingguan, bulannan, catatan anekdot, penilaian hasil karya.

Yang tercantum dalam format ianpenilaian harian pada template Siperan (Sistem Perangkat

Pembelajaran) anatara lain mencantumkan:

1. identitas lengkap

2. periode penilaian,

3. lingkup perkembangan

4. indikator penilaian

5. mencantumkan nama peserta didik.

Berbeda dengan format skala capaian perkembangan harian yang merangkum pencapaian anak sekelas, pada rekap penilaian mingguan menyajikan laporan perkembangan masing-masing anak. Yang tercantum dalam format rekap penilaian mingguan pada template Siperan (Sistem Perangkat

Pembelajaran) anatara lain mencantumkan:

1. nama anak

2. periode penilaian

3. kelompok

4. semester

5. Program Pengembangan

6. $\mathrm{KD}$

7. Uraian $\mathrm{KD}$

8. Scoring tiap minggu dalam periode satu bulan Nilai akhir

8. Komponen Penilaian Rekap ceklis bulanan juga Bulanan menyajikan perkembangan 


\begin{tabular}{|c|c|c|}
\hline & & $\begin{array}{l}\text { masing-masing anak. } \\
\text { Komponennya meliputi: } \\
\text { 1. Nama anak } \\
\text { 2. Semester } \\
\text { 3. Kelompok } \\
\text { 4. Program pengembangan } \\
\text { 5. KD } \\
\text { 6. Uraian KD } \\
\text { 7. Scoring tiap bulan dalam } \\
\text { 8. Nilai akhir semester }\end{array}$ \\
\hline & Catatan Anekdot & $\begin{array}{l}\text { Catatan anekdot memiliki } \\
\text { komponen: }\end{array}$ \\
\hline & & $\begin{array}{ll}\text { 1. } & \text { Kelompok } \\
\text { 2. } & \text { Semester } \\
\text { 3. } & \text { Nama guru } \\
\text { 4. } & \text { Tanggal } \\
\text { 5. } & \text { Nama anak } \\
\text { 6. } & \text { Tempat } \\
\text { 7. } & \text { Waktu } \\
\text { 8. } & \text { Peristiwa } \\
\text { 9. } & \text { Capaian kompetensi }\end{array}$ \\
\hline 10. & $\begin{array}{l}\text { Penilaian Hasil Karya dan } \\
\text { Unjuk Kerja }\end{array}$ & $\begin{array}{l}\text { Walaupun template siperan } \\
\text { menyajikan format penilaian } \\
\text { hasil karya dan unjuk kerja, } \\
\text { namun format ini jarang } \\
\text { digunakan oleh guru. } \\
\text { Guru lebih senang langsung } \\
\text { memberikan reward berupa } \\
\text { bintang dan catatan pada } \\
\text { hasil karya anak secara } \\
\text { langsung. }\end{array}$ \\
\hline
\end{tabular}

Berdasarkan kesimpulan di atas, hal tersebut menunjukkan bahwa Siperan membantu proses pekerjaan menyusun perangkat pembelajaran menjadi lebih mudah dan efisien serta berguna untuk menyelesaikan RPPM dan RPPH satu periode dengan tepat waktu, begitu pula dengan proses penyusunan penilaian harian, mingguan, bulanan dan catatan anekdot yang dapat terselesaikan dengan segera.

Dari data yang diperoleh selama penelitian implementasi siperan berbasis single user dalam penyusunan perangkat pembelajaran di KB-TK Islam Al Fath Semarang, maka dapat diketahui bahwa siperan memiliki tempalate yang lengkap dan terintegrasi dalam satu sistem perangkat pembelajaran yang memudahkan pemakainya.

\section{PEMBAHASAN}

Pada umumnya guru sudah mampu membuat bahan pembelajaran. Kebutuhan saat ini ketika guru diminta untuk membuat bahan pengembangan dengan menggunakan teknologi menjadi tantangan bagi guru untuk menguasai teknologi agar dapat membuat bahan pembelajaran. (Arsanti, 2018) peserta didik mengharapkan dan membutuhkan terhadap pengembangan bahan ajar kreatif. Penguasaan guru terhadap teknologi merupakan modal untuk membuat bahan ajar. Penguasaan yang baik akan membantu guru untuk membuat bahan ajar yang lebik kratif. Kreatifnya seorang guru akan memberikan warna dari bahan ajar sehingga akan memberikan daya tarik dari pembelajaran yang diberikan di kelas. Kondisi ini memberikan nilai tawar guru untuk dapat mengendalikan pembelajaran agar lebih baik lagi. Dengan media yang diminati anak partisipasi anak lebih meningkat dalam proses pembelajaran. (Zakiah, Suyono, \& Roekhan, 2012) guru merupakan orang yang dijadikan tempat bertanya oleh peserta didik dalam pembelajaran, guru merupakan orang yang membantu untuk memberikan jawaban dari pembelajaran yang dilaksanakan oleh karena iitu guru diharapkan sudah mempersiapkan dengan baik sebelum pembelajaran dimulai. (Romansyah, 2016) pemilihan dan penyajian bahan ajar harus sesuai dengan kriteria penulisan yang berlaku umum seperti prinsipprinsip, tahap-tahap pemilihan, prinsip pemilihan, dan kriteria penyajian bahan ajar.

Siperan (Sistem Perangkat Pembelajaran) single user sangat membantu dalam proses pembelajaran terutama mempermudah pendidik dalam menyusun perangkat pembelajaran (Rencana Pembelajaran dan Penilaian) selain itu tampilan perangkat pembelajaran yang disusun 
menggunakan siperan mudah untuk dipahami dan dalam hal ini ditunjukkan dalam hasil kuesioner atau angket di mana responden (guru) menyatakan tidak kesulitasn dalam pengoperasian sistem perangkat pembelajaran berbasis single user, walaupun ada yang kurang bisa mengoperasikan komputer akan tetapi berusaha untuk menggunakannya karena proses penyusunan perangkat pembelajaran melalui siperan single user waktu pengerjaannya lebih singkat, lebih sistematis dan lebih mudah. Solusi dalam menyelesaikan kesulitan yang guru hadapi dalam mengimplementasikan siperan sebagian guru akan bertanya pada teman yang tahu tentang komputer.

\section{SIMPULAN DAN SARAN}

\subsection{Simpulan}

Berdasarkan hasil penelitian dan pembahasan bahwa Perangkat pembelajaran memiliki tujuan untuk memenuhi suatu keberhasilan guru dalam pembelajaran. Perangkat pembelajaran sendiri yaitu sebuah media yang digunakan sebagai pedoman atau petunjuk pada sebuah proses pembelajaran. Perangkat adalah sejumlah bahan, alat, media, petunjuk dan pedoman yang akan digunakan dalam proses pencapaian kegiatan yang diinginkan. Pembelajaran adalah proses kerjasama antara guru dan siswa dalam memanfaatkan segala potensi dan sumber yang ada, baik potensi yang bersumber dari diri siswa itu sendiri seperti minat, bakat, dan kemampuan dasar yang dimiliki termasuk gaya belajar maupun potensi yang ada di luar diri siswa seperti lingkungan, sarana, dan sumber belajar sebagai upaya untuk mencapai tujuan belajar tertentu (Sanjaya, 2010:26).
Siperan (Sistem Perangkat Pembelajaran) single user sangat membantu dalam proses pembelajaran terutama mempermudah pendidik dalam menyusun perangkat pembelajaran (Rencana Pembelajaran dan Penilaian) selain itu tampilan perangkat pembelajaran yang disusun menggunakan siperan mudah untuk dipahami. Bilamana ada yang kurang bisa mengoperasikan komputer akan berusaha untuk menggunakannya karena proses penyusunan perangkat pembelajaran melalui siperan single user waktu pengerjaannya lebih singkat, lebih sistematis dan lebih mudah. Solusi dalam menyelesaikan kesulitan yang guru hadapi dalam mengimplementasikan siperan sebagian guru akan bertanya pada teman yang tahu tentang komputer.

\subsection{Saran}

Berdasarkan simpulan diatas, untuk Implementasi Siperan (Sistem Perangkat Pembelajaran) berbasis Single User dalam penyusunan perangkat pembelajaran maka peneliti memberikan saran kepada:

\section{Guru}

a. Senantiasa meningkatkan keterampilannya dalam hal penggunaan komputer

b. Lebih kreatif dan inovatif dalam bekerja

c. Disiplin dalam menyesaikan setiap tugas yang dihadapinya

\section{Kepala Sekolah}

a. Memberikan kesempatan kepada guru untuk meningkatkan kompetensi guru

b. Mencarikan solusi bilamana ada guru yang mengalami kesulitan atau hambatan dalam menyelesaikan tugasnya

\section{Sekolah}


a. Memfasilitasi guru untuk dapat lebih berkembang, khususnya keterampilan dalam bidang komputer

Memberikan propgram peningkatan kompetensi guru secara terprogram atau kontinu

\section{PERNYATAAN TERIMA KASIH}

Terima kasih dan penghargaan atas dukungan dan kontribusi dari pihak-pihak dan rekan-rekan sejawat dan keluarga besar KB-TK Islam Al Fath Semarang yang telah membantu proses penelitian ini.

\section{REFERENSI}

Anggreni, M. A. 2017. Kompetensi Guru Paud Di Kelurahan Balas Klumprik Dalam Mengembangkan Perangkat Pembelajaran.Buana Pendidikan: Jurnal Fakultas Keguruan dan Ilmu Pendidikan, 13(23), 28-40.

Arfida, S. 2015. "IbM Untuk Peningkatan Kompetensi Guru Dalam Penggunaan Aplikasi Komputer Di Bandar Lampung". Jurnal Teknologi Informasi dan Bisnis Pengabdian Masyarakat Darmajaya, 1(2), 83-91.

Barus, G. "Perancangan Model Hipotetik".

Dhewy, R. C. 2018. "Pelatihan Dasar-Dasar Statistika Dengan Menggunakan Aplikasi Microsoft Excel Di Sdn Pamotan Ii Kecamatan Porong". Jurnal PADI-Pengabdian mAsyarakat Dosen Indonesia, 1(1), 36-40.

Hardiyana, A. 2016. "Optimalisasi pemanfaatan teknologi informasi dan komunikasi dalam pembelajaran PAUD". AWLADY: Jurnal Pendidikan Anak, 2(1).

Hartuti, P. M., Nurullaeli, N., \& Nugraha, A. M. 2020. "Pengembangan Keterampilan Para Guru dalam Pengelolaan Administrasi Sekolah Berbasis Microsoft Excel”. E-Dimas: Jurnal Pengabdian kepada Masyarakat, 11(1), 115-118.

Hasmalena, H., \& Syafdaningsih, S. S. 2017. Pelatihan Pembuatan Perangkat
Pembelajaran Berbasis Scientific Pada Guru Paud Di Kel. Talang Kelapa Kecamatan Alang-Alang Lebar Palembang. Jurnal Kreatif: Jurnal Kependidikan Dasar, 8(1).

Hermanto, H., Marsudi, M., Subali, E., \& Hendrajati, E. 2018. "Efektifitas Tik Untuk Peningkatan Proses Belajar Mengajar Di Paud, Tk Dan Madrasah Diniyah "Mamba'ul Hisan Dusun Sekargadung, Desa Balerejo Ii, Kecamatan Panggungrejo, Kabupaten Blitar". IPTEK Journal of Proceedings Series, (5), 77-84.

htpps:/dunia pendidikan.co.id/perangkatpembelajaran/ diakses tanggal 26 Maret 2020.

https://adotuek.blogspot.com/2017/03/pengertiandan-fungsi-microsoft-excel.html [diakses tanggal 26 Maret 2020]

https://www.temukanpengertian.com/2013/01/peng ertian-sistem-operasi-single-userhtml[diakses tanggal 26 Maret 2020]

https:/www.temukanpengertian.com/2013/01/peng ertian-sistem-operasi-single-userhtml[diakses tanggal 26 Maret 2020]

Kurniawati, E., Haenilah, E. Y., \& Fatmawati, N. "Studi Deskriptif Profesionalisme Guru TK dalam Pembelajaran Anak Usia Dini di Kecamatan Bandar Sribhawono Kabupaten".

Limbong, I., Munawar, M., \& Kusumaningtyas, N. 2019, December. Perencanaan Pembelajaran Paud Berbasis Steam (Science, Technology, Eingeneering, Art, Mathematic). In Seminar Nasional PAUD 2019 (pp. 203-212).

Madcoms Madiun. 2017. Rumus dan Fungsi Terapan pada Microsoft Excel untuk Mengolah Data dan Lapran. Yogyakarta: Penerbit Andi.

Maisyarah, R., Purwaningsih, E., \& Buwono, S. "Efektivitas Penerapan Aplikasi Microsoft Office pada Pembelajaran Akuntansi di Kelas X Smk". Jurnal Pendidikan dan Pembelajaran Khatulistiwa, 5(9).

Martiningsih, R. R. 2015. "Efektivitas Pemanfaatan Ms Excel Dalam Pembelajaran Matematika Di Smp Muhammadiyah Surabaya". Kwangsan, 3(2), 107-120.

Marzuqi, N. H. 2013, March. Sistem Informasi Single User Penerimaan Peserta Didik 
Baru Berbasis Php Di Sekolah Menengah Pertama Islamiyah Widodaren Ngawi. In Seruni-Seminar Riset Unggulan Nasional Inoformatika dan Komputer (Vol. 2, No. 1).

Moleong, Lexy J. 2014. Metodologi Penelitian Kualitatif. Bandung: Remaja Rosdakarya.

Mulyana, Edi S. 2005. Pengenalan Protokol Jaringan Wireless Komputer. Jogjakarta: Penerbit Andi.

Nana, S. S. 2010. Metode penelitian pendidikan. Bandung: Remaja Rosdakarya.

Peraturan Menteri Pendidikan dan Kebudayaan No. 137 Tahun 2014 tentang Standar Nasional Pendidikan Anak Usia Dini.

Pramudyani, A. V. R., \& Rohmadheny, P. S. 2019, September. "Pelatihan pemanfaatan aplikasi microsoft office dalam pembelajaran sebagai upaya peningkatan profesionalisme bagi guru PAUD di PCA Mantrijeron". In Seminar Nasional Hasil Pengabdian Kepada Masyarakat (pp. 711-718).

Prastowo, Andi. 2015. Menyusun Rencana Pelaksanaan Pembelajaran (RPP) Tematik Terpadu. Jakarta: Kencana.

Rahelly, Y. 2018. "Implementasi Kurikulum 2013 Pendidikan Anak Usia Dini (PAUD) di Sumatera Selatan". Jurnal Pendidikan Usia Dini, 12(2), 381-390.

Rinusantoro, S., \& Kom, S. Pengenalan Sistem Operasi

Rohita, dkk. 2019. "Sistem Informasi Perangkat Pembelajaran untuk Meningkatkan Kualitas Pendidik Anak Usia Dini”. Diakses dari laman http://jurnal.umj.ac.id/index.php/semna skat. Pada tanggal 10 Maret 2020 pukul 19.20 WIB.

Rokhzi, M. F. 2016. Pendampingan Ikatan Guru Raudlatul Athfal (Igra) Kecamatan Sooko Mojokerto Dalam Pengembangan Perangkat Pembelajaran Kurikulum 2013. Repository, 1(1), 125.

Rusilowati, A. 2013. Pengembangan Perangkat Pembelajaran Metode Discovery Learning Untuk Pemahaman SAINS Pada Anak TK B. Journal of Primary Education, 2(2), 71-76.
Sanjaya, Wina. 2010. Strategi Pembelajaran Berorientasi Standar Proses Pendidikan. Jakarta : Prenada Media Group

Sari, A. M., \& Burhan, M. A. 2020. Pengembangan Perangkat Pembelajaran Berbasis Model Sentra. Jurnal Pelita PAUD, 5(1), 76-81.

Satya, B. 2010. "Mengenal Sistem Operasi Yang Beredar Disekitar Kita". Data Manajemen dan Teknologi Informasi (DASI), 11(2), 19.

Sofia, A., Fatmawati, N., DRUPADI, R. D., Nawangsasi, D., Sugiana, S., \& Irzalinda, V. 2019. Pelatihan Penyusunan Perangkat Pembelajaran Kurikulum 2013 Bagi Guru Pendidikan AnakUsia Dini (PAUD). In Prosiding seminar nasional pendidikan Forkom PG PAUD 2019 (pp. 8-14). Lembaga Penelitian dan Pengabdian Kepada Masyarakat Universitas Lampung.

Sugiarto, E., Kom, S., \& Kom, M. Arsitektur

Sistem Basis Data.

Sugiyono. 2017. Metode Penelitian Kualitatif, Kuantitatif, dan $R$ \& D. Bandung: Alfabeto.

Sugiyono. 2018. Metode Penelitian Kualitatif. Bandung: Alfabeto

Sunarto. 2006. TIK SMA/MA Kls $X$. Jakarta: Grasindo.

Tirtayani, L. A., Wirabrata, D. G. F., \& Sujana, I. W. 2019. Pelatihan penyusunan perangkat pembelajaran menggunakan pendekatan saintifik. Widya Laksana, 8(2), 151-160.

Trianto. 2011. Desain Pengembangan Pembelajaran Tematik Bagi Anak Usia Dini TK/RA \& Anak Usia Kelas Awal SD/MI. Jakarta: Kencana.

Undang-Undang Nomor 20 Tahun 2003 tentang Sistem Pendidikan Nasional.

Undang-Undang Nomor 14 Tahun 2005 tentang Guru dan Dosen.

Wahana Komputer. 2008. Menjadi Teknisi Komputer Profesional. Jakarta: PT. Elex Media Komputindo.

Wahyuni, M. dkk. 2018. Penyusunan Rencana Pelaksanaan Pembelajaran Pendidikan Anak Usia Dini. Jakarta: Direktorat Pembinaan Pendidikan Anak Usia Dini Direktorat Jenderal Pendidikan Anak Usia Dini dan Pendidikan Masyarakat Kementrian Pendidikan dan Kebudayaan. 
Widiasari, Y. 2018. Pengembangan Perangkat Pembelajaran di PAUD

Gemilang. KHAZANAH PENDIDIKAN, 11(1).

Widoyoko, S. 2017. Teknik Penyusunan Instrumen Penelitian. Yogyakarta: Pustaka Pelajar.

Wulandari, R., Hayati, N., Muthmainnah, M., \& Fatimaningrum, A. S. 2018. Stimulasi Penyusunan Perangkat Pembelajaran Kurikulum 2013 Paud Bagi Pendidik Paud Di Kecamatan Banguntapan Bantul. Jurnal Pendidikan Anak, 7(1), 93-100. 